\author{
アルミニウムのジンケート処理 \\ 川島敏 ${ }^{\mathrm{a}}$ \\ aメルテックス(株) 技術開発部 ( ⿳ 331-0811＼cjkstart埼玉県さいたま市北区吉野町 2-3-1)

\section{Zincate Process of Aluminum}

Satoshi KAWASHIMA ${ }^{\text {a }}$

${ }^{a}$ Technology Development Department, Meltex Inc. (Yoshino-Cho 2-3-1, Kita-ku, Saitama-shi, Saitama 331-0811)

Keywords : Aluminum, Aluminum Alloy, Zincate, Pre Treatment

\section{1.はじめに}

アルミニウムは, 軽量で加工性がよく, 適度な電気伝導性 を持ち, 自動車, 機械, 電子等々あらゆる分野で幅広く用い られている。一方，アルミニウムの柔らかく精密加工に向か ないという特性を改善するために, 電解, 無電解を問わずさ まざまなめっきが行われている ${ }^{1)}$ 。その前処理で特異的かつ 重要なのがダブルジンケート法と呼ばれる二段の亜鉛置換処 理である。ジンケート処理はアルミニウムの電解めっき, 無 電解めっきの前処理として古くから用いられている処理であ るがその詳細について解説された成書は極めて少ない。本稿 を執筆するにあたり, 数冊の表面処理に関する解説書を確認 したが, ジンケート処理に関する記述はわずかであった。本 稿では, ジンケート処理の歴史とその組成や反応, さらに近 年の研究やプロセス改良についてまとめる。

\section{2. ジンケート処理の歴史}

アルミニウムは大気中, 水中で容易に酸化膜を形成する性 質を持つ。この酸化膜によって，アルミニウムは良好な耐食 性を示すが，一方でこの酸化膜がめっき皮膜との間に存在す ると, めっき膜の密着を阻害する要因となる。アルミニウム へのめっきにおいて, この酸化膜への対処法が課題であった。

アルミニウムの酸化膜を溶解し, 置換反応で亜鉛皮膜を形 成するジンケート処理の最も古い例は, Hewitsonの 1927 年
の米国特許と考えられる ${ }^{2), 3)}$ 。この特許では, ジンケート処 理液は水酸化ナトリウム, 塩化車鉛およびタンニン酸ナトリ ウムまたはでんぷんからなる組成で, 処理は一回だけ行われ ており, 充分な密着は得られなかったのではないかと推測さ れる。1939 年には, Korpium がジンケート処理液に銅を添 加し，第一亜鉛置換皮膜を硝酸で剥離し，二回目のジンケー ト処理を行うダブルジンケート法により密着の改善を試みて いる ${ }^{4)}$ 。さらに 1950 年代には, Zalley が密着と耐食性を改 善するためにジンケート処理の組成を検討し，塩化鉄とロッ セル塩を添加した組成を発表している ${ }^{5)}$ (表 1)。

ジンケート処理による亜鉛置換量は, ジンケート処理液の 組成, 温度, 処理時間, そしてアルミ合金種に依って大きく 変化するため，その影響が検討されている ${ }^{6)}$ 。

ジンケート処理は電解めっきの前処理として開発されたが, 無電解めっきの前処理としても用いられるようになってきた。 Baudrand ${ }^{7)}$ によると, 1970 年代の終わりには，はんだ付け性 と耐食性から熱交換器に, 良好な離型性からロウ用金型に, 耐摩耗性から電鋳心棒に, 潤滑性から小型のエンジンブロッ クに，等，幅広い分野の機械部品に用いられている。

1980 年代に, ハードディスクの磁気ディスク基板にアル ミニウムが用いられるようになると, 膜厚の均一性に優れて いること, 非磁性であること, 硬度が充分に高いこと, 非晶 質で研磨性が良好であることから無電解ニッケルめっきが下 地に用いられるようになり, ダブルジンケート処理もその前

表 1 ジンケート処理液の組成例

\begin{tabular}{|c|c|c|c|c|c|c|c|}
\hline & Hewitson $^{3)}$ & Kopium $^{4)}$ & Zelley ${ }^{5)}$ & Yonemitsu $^{9)}$ & Lashmore $^{13)}$ & Morikawa $^{20)}$ & Tashiro $^{23)}$ \\
\hline 塩化亜鉛 & 50 & & & & & & \\
\hline 酸化垔鉛 & & 80 & 100 & 50 & 100 & 20 & 25 \\
\hline 水酸化ナトリウム & 150 & 400 & 400 & 260 & 525 & 120 & 170 \\
\hline タンニン酸ナトリウム & 20 & & & & & & \\
\hline シアン化銅カリウム & & 5 & & & & & \\
\hline 亜硫酸ジナトリウム & & 25 & & & & & \\
\hline 塩化第二鉄 六水和物 & & & 1 & 2 & 1 & & 2 \\
\hline 酒石酸 & & & 5 & 50 & 10 & 10 & \\
\hline 錯化剤 & & & & & & & 10 \\
\hline
\end{tabular}


処理として用いられるようになった ${ }^{8)}$ 。ハードディスクの記 録密度増加に伴い, より平滑で表面欠陥のない無電解めっき 皮膜が求められるようになり，ジンケートを含めた前処理工 程の影響が検討されている ${ }^{9)}$ 。

1990 年代には半導体デバイスの高密度実装のために, 半 導体チップの能動素子面の電極にはんだバンプを形成し, チップサイズで基板に実装するフリップチップ実装が実用化 された。はんだバンプを形成するための電極はアルミニウム 合金で形成されており，はんだ接合するためにはアルミニウ ムのはんだ濡れ性は充分でない。このため, はんだ需れ性の 向上およびはんだバンプ構成成分の半導体チップへの拡散防 止のためにバンプ下部に保護膜(Under Barrier Metallization $\mathrm{UBM})$ を形成する必要がある。UBM を半導体デバイスの内 部配線と同様に真空製膜法で形成すると, ウエ八全面に金属 多層膜の成膜後, パターン形成のためにフォトリソグラ フィーでレジストを形成し，エッチング処理が必要であり， プロセスが長く，かつ，高コストになる。このため，短工程， 短時間で UBM 形成が可能である無電解めっきによる UBM 形成法が開発された ${ }^{10)}$ 。UBM を形成する電極は直径数十〜 数百 $\mu \mathrm{m}$, 厚さ $0.5 \sim 1 \mu \mathrm{m}$ の微小薄膜電極で, 既存のジンケー 卜処理液では, 電極の過剩なエッチング, 電極材質や電極電 位へ依存した特性変化, 電極の局部腐食が発生するため, 前 処理プロセス全般の改良が検討されている ${ }^{11)} 。$

\section{3. ジンケート処理の反応機構}

ジンケート処理の反応機構については, 無電解ニッケル めっき前処理に多用され始めた 1980 年代から数多くの検討が

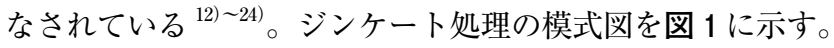

処理前のアルミニウム表面には自然酸化膜が形成されてい る。安住らは5 586 系アルミニウムをジンケート液に浸漬した 時の電位変化からこの酸化皮膜膜厚を $0.5 \sim 5 \mathrm{~nm}$ 程度と ${ }^{17)}$, 森河らはA1085 系アルミニウムをXPS での深さ分析から約 $7.7 \mathrm{~nm}$ と ${ }^{20)}$, それぞれ見積もっている。ジンケート液は強ア ルカリ性亜鉛溶液で, この処理液にアルミニウムを浸漬すると,
まず(1)の反応によりアルミニウムの酸化皮膜が溶解する。

$$
\mathrm{Al}_{2} \mathrm{O}_{3}+2 \mathrm{OH}^{-}+3 \mathrm{H}_{2} \mathrm{O}=2 \mathrm{Al}(\mathrm{OH})_{4}
$$

ついで，亜鉛置換液中に露出したアルミニウム部分で，ア ルミニウムの溶解と亜鉛の析出が起こり, その結果として亜 鉛粒子が成長する。

$1 / 3 \mathrm{Al}+4 / 3 \mathrm{OH}=1 / 3 \mathrm{Al}(\mathrm{OH})_{4}{ }^{-}+\mathrm{e}$

$1 / 2 \mathrm{Zn}(\mathrm{OH})_{4}{ }^{2-}+\mathrm{e}=1 / 2 \mathrm{Zn}+2 \mathrm{OH}$

Lashmore によると, 反応 $(2)$ および $(3)$ に従って反応が進 行するのは水酸化ナトリウムと酸化亜鉛からなるジンケート 液のみで, 塩化鉄とロッシェル塩を含むジンケート液では, アルミニウムの溶解原子数と覀鉛の析出原子数の比が上式に 従わず, 異なる析出反応が進行していると示唆している ${ }^{12) 。 ~}$ 安住らは, 純度 $99.999 \%$ のアルミニウムでの鉄塩と錯化剂 を含むジンケート処理液による亜鉛置換反応について，水酸 化ナトリウムと酸化亜鉛からなる単純浴と比較して, 詳細な 検討を行っている ${ }^{18)}$ 。水酸化ナトリウムと酸化覀鉛から成 るジンケート液では，第一覀鉛置換では六方晶を基本とする 亜鉛粒子が析出し，30 秒でほぼ表面を被覆, 浸漬電位も亜 鉛とほぼ等しい電位に収束する。一方, 鉄塩と錯化剂を含む ジンケート液では，亜鉛粒子に鉄が共析し，粒子サイズが小 さく, 六方晶型の結晶成長が阻害され, 結晶型に乱れが見ら れる。浸漬電位も水酸化ナトリウムと酸化亜鉛からなる浴と 比較して卑の方向にシフトし, 亜鉛粒子への鉄の共析が電気 化学的挙動を大きく変化させていることが明らかになった。

次工程の硝酸浸漬処理でこの亜鉛置換皮膜は溶解し，その 後の水洗過程で, アルミニウムの表面には, 表面形状に追随 した厚さ $0.3 \mathrm{~nm}$ の均一で薄い酸化皮膜が形成される ${ }^{17)} 。 こ$ の表面には亜鉛が残存することがXPS 分析から求められて いる ${ }^{19), 20)}$ 。

二回目のジンケート処理ではこの薄く均一な酸化皮膜は短 時間で溶解され，第一亜鉛置換よりも多くの核発生点で亜鉛 置換反応が進行する。この結果として薄く均一な亜鉛置換皮 膜が形成される。特に, 鉄塩を含むジンケート液では層状の 亜鉛成長が阻害され，微粒子状に析出する ${ }^{18)}$ 。
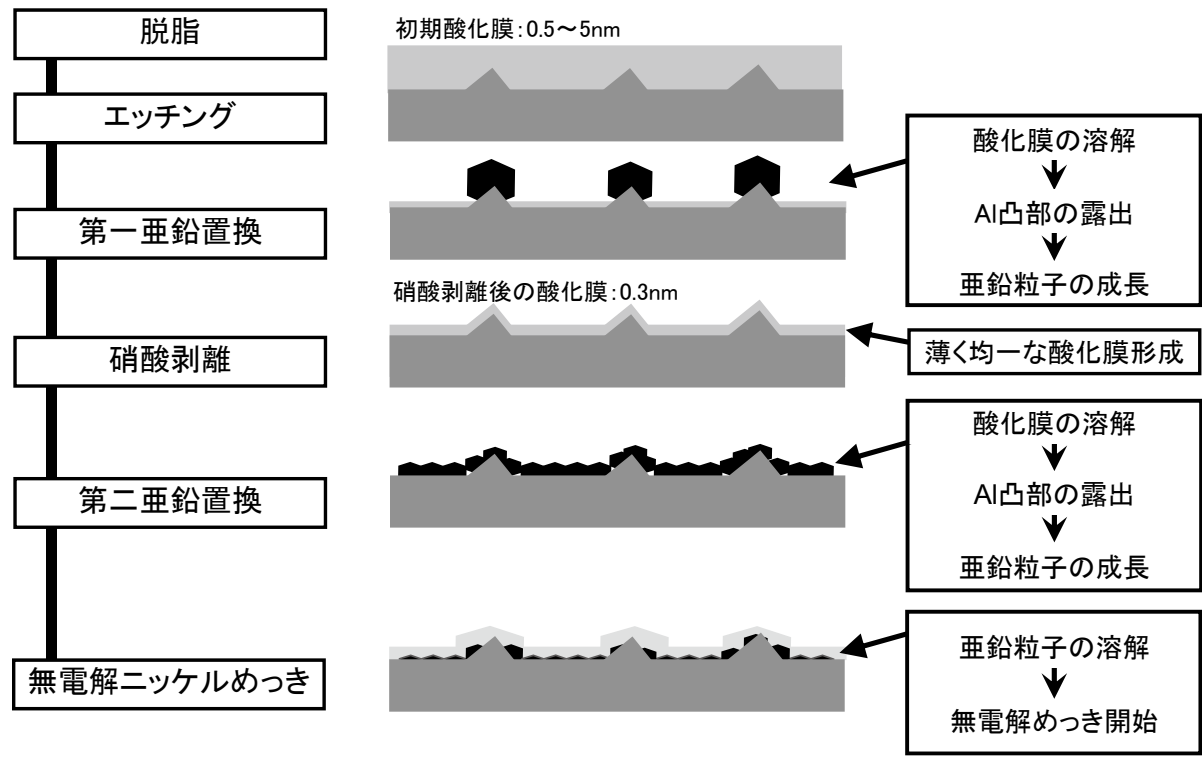

図 1

ジンケート処理の模式図 
亜鉛置換反応は, ジンケート液組成以外に, 温度やアルミ ニウム合金種に依っても大きく変化する ${ }^{6), 14,22)}$ 。中田らは $\mathrm{Al}$ 単結晶表面へジンケート処理および無電解ニッケルめっ きを行い, 結晶面の違いに起因する亜鉛粒子の成長過程を検 討している ${ }^{21)}$ 。

ジンケート処理と無電解ニッケルめつきの関係についても,

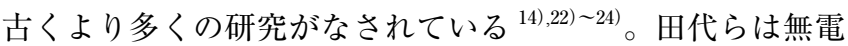
解ニッケルめっきの初期析出を観察した結果から, 無電解 ニッケルめっき液中で，第二亜鉛置換皮膜上ではまず覀鉛と ニッケルの置換反応が起こり, ついでこのニッケル皮膜上で 無電解ニッケルめっき反応が進行すると推定した。また， ウ ルトラミクロトームを用いて作成した無電解ニッケルめっき 皮膜の TEM 観察より, 無電解ニッケルめっき皮膜とアルミ ニウムの界面に，ジンケート処理により生成したアルミニウ ムの島状突起の上部に亜鉛が残留しており, 残留亜鉛と無電 解ニッケルめっき皮膜の境界に置換反応で生じたニッケルと 考えられる層が存在することを見いだしている ${ }^{23)}$ 。

\section{4. 微小薄膜へのジンケート処理}

半導体デバイス内部の金属配線には，電気伝導率，耐熱性， コスト, 化学的安定性, $\mathrm{Si}$ や $\mathrm{SiO}_{2}$ との反応性, 接着性といっ た観点からアルミニウムが用いられてきた。アルミニウムは エレクトロマイグレーション現象によって, 通電時に移動し やすい性質を持ち，その防止策として，チタン系材料を用い た積層構造を取る方法，および，アルミニウムに $0.5 \sim 1.0 \%$ の $\mathrm{Si}$ や $\mathrm{Cu}$ を添加する方法がとられている。半導体デバイス 最外層の接合用電極も $\mathrm{Al}, \mathrm{Al}-\mathrm{Si}, \mathrm{Al}-\mathrm{Cu}, \mathrm{Al}-\mathrm{Si}-\mathrm{Cu}$ といった 真空製膜法で成膜された厚さ数 $\mu \mathrm{m}$ オーダーのアルミニウム 合金である。既に述べたように，ジンケート処理はアルミニ ウムの局部溶解を含む反応であり，薄膜への適用が困難であ ると考えられていた。しかしながら，アルミニウムに選択的 に処理が可能で，フォトリソグラフィーによるレジスト形成 工程を使うことなく独立パターンにめっきができる無電解 めっきは魅力的な工法である。半導体デバイスのアルミニウ ム合金電極へのジンケート処理, 無電解めっき処理は 1980 年代より報告されており ${ }^{25), 26)}$ ，ジンケート液の成分が亜鉛 置換皮膜に与える影響 ${ }^{27)}$ や良好な形状のめっき皮膜を得る ためのジンケート処理条件 ${ }^{28)}$,29) 等が報告されている。その 結果として，微細な亜鉛置換膜程高い接合強度を示す傾向が 求められている ${ }^{28), 29)}$ 。これらの結果は, 半導体デバイスの アルミニウム合金電極では専用の亜鉛置換組成，処理条件が 必要となることを示唆している。

半導体デバイスのアルミニウム合金電極へのめっきプロセ スは基本的には図 1 に示したものと同様である。しかしなが ら，一般的なジンケートプロセスを用いた場合，図 2 に示す ような薄膜特有の問題が生じる。

ジンケート処理中は亜鉛析出が局所的に進行するため, ア ルミニウムの溶解が進み, 図 2 a) に示すように電極が部分的 に浸食され，極端な場合は電極がすべて溶解してしまうこと がある。電極材質や電極電位に依って, 亜鉛置換皮膜の形成 が困難である場合がある。特に, Al-Si 電極では, $\mathrm{Al}$ 電極, $\mathrm{Al}-\mathrm{Cu}$ 電極, $\mathrm{Al}-\mathrm{Si}-\mathrm{Cu}$ 電極と比較して, 均一な亜鉛置換膜が
得られず，図 2 b) に示すようにノジュールの多いめっきとな る傾向が見られる。めっき後の断面を観察すると (図 $2 \mathrm{c}$ )), 薄膜電極に無電解ニッケルめっきが入り込む「ニッケルスパ イク」と呼ばれる現象が多発する。

これらの問題は, アルミニウム合金薄膜電極をダブルジン ケート処理による無電解ニッケルめっきを導入された当初に 問題となった。筆者らは既存のダブルジンケートプロセスを 見直し, 現在はこれらの問題は解消されている。以下にその 概要を述べる。

\section{1 ジンケート液組成の検討}

一回目のジンケート処理において, 酸化膜が溶解しアルミ ニウムが露出した部分から亜鉛の析出が始まり，粒子成長が 粒子発生よりも優先して進行するため, アルミニウムが露出 した部分での溶解が進行し，図 2 a)に示すような浸食生じる。 ジンケート液組成を検討した結果，亜鉛の析出を抑制する成 分を添加することで図 3 に示すような微細な粒径の亜鉛置換 皮膜を形成することが可能となった。一般的なジンケート液 で処理した電極表面では，直径 $0.3 \sim 1.0 \mu \mathrm{m}$ の亜鉛粒子が まばらに分布する(図 3 a)) のに対して，薄膜用ジンケート液 で処理した表面では直径約 $0.3 \mu \mathrm{m}$ の均一な粒子が緻密に析 出している(図 3 b ) )。これらの亜鉛置換皮膜を硝酸で剥離し たあとの表面を比較すると(図 4), 一般的なジンケート液で 処理した電極表面(図 4 a))では, アルミニウムの突起部分と 深く侵食された部分が認められる。これに対して，薄膜用ジ ンケート液で処理した電極表面(図 4 b) ) では侵食が均一に進
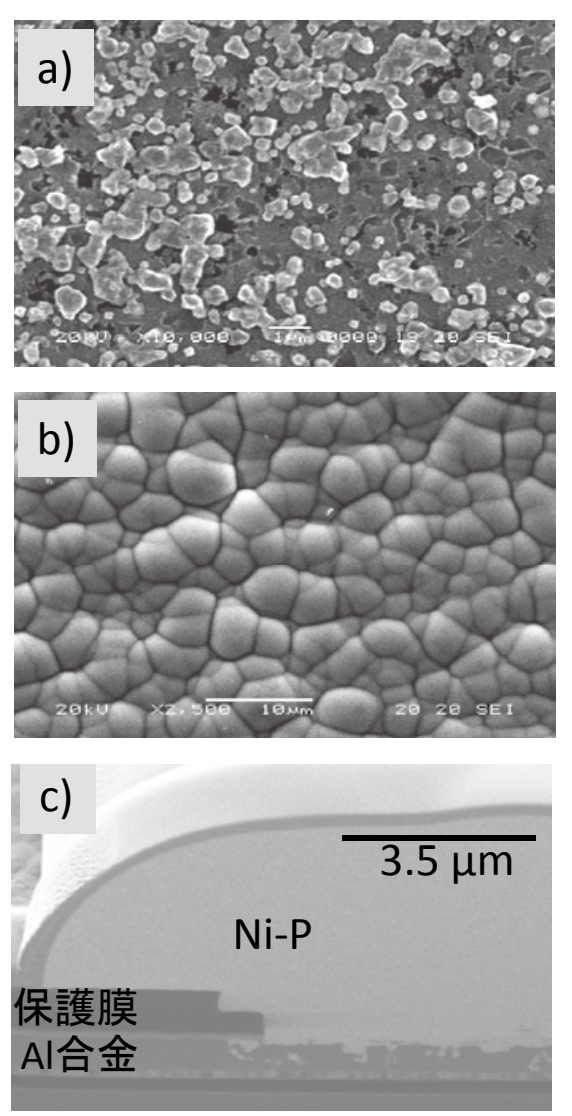

図 2 半導体電極での問題

a) 電極の浸食, b) Al-Si 電極でのノジュラ スな析出, c) Ni スパイク 
行し，一般的なジンケート液で処理した電極表面で見られた ような深く侵食された部分はほとんど認められない。

\section{2 前処理プロセスの再構築}

$\mathrm{Al}-\mathrm{Si}$ 電極の場合, 図 5 a) に示すように第一ジンケート処 理で亜鉛粒子が局所的に生成・成長しやすい傾向を示す。第 二ジンケート処理においても局所的に亜鉛置換膜が生成しや すい傾向は同様で，これがノジュラスな無電解ニッケルめっ き皮膜が析出する原因となる。第一ジンケート処理での亜鉛
置換反応を促進するために，アルミニウム表面に核生成を促 進するようにプロセスを最適化すると, 図 $5 \mathrm{~b}$ )のような均質 な亜鉛置換皮膜の生成と亜鉛置換粒子の微細化を達成するこ とができている。

反応抑制だけではアルミニウムの浸食抑制は不充分で，第 一覀鉛置換皮膜を剥離したあとの表面を観察すると孔食の生 成が認められる(図6 a))。小山らは，ハードディスク用アル ミニウムディスクの前処理において, 孔食とアルミニウム/
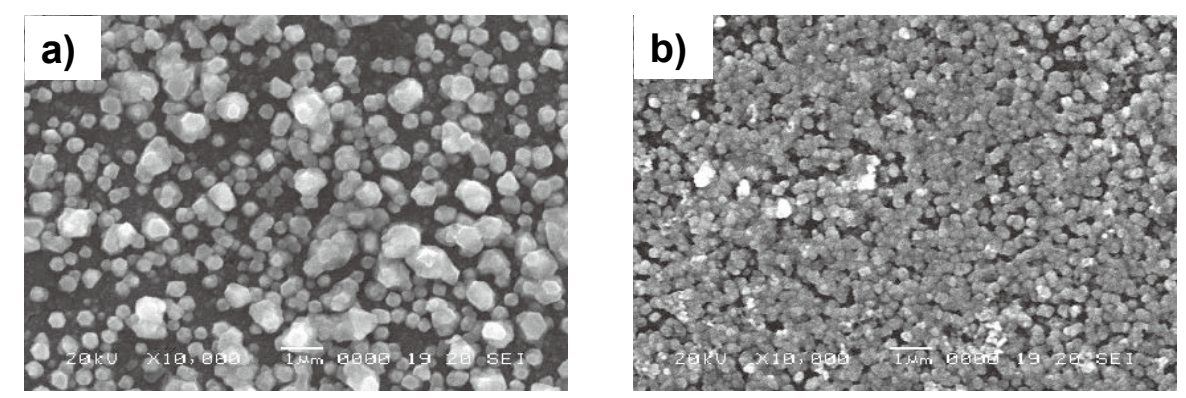

図 3 第一ジンケート処理後の Al-Si 電極表面 a)一般用ジンケート処理，b) 薄膜用ジンケート処理
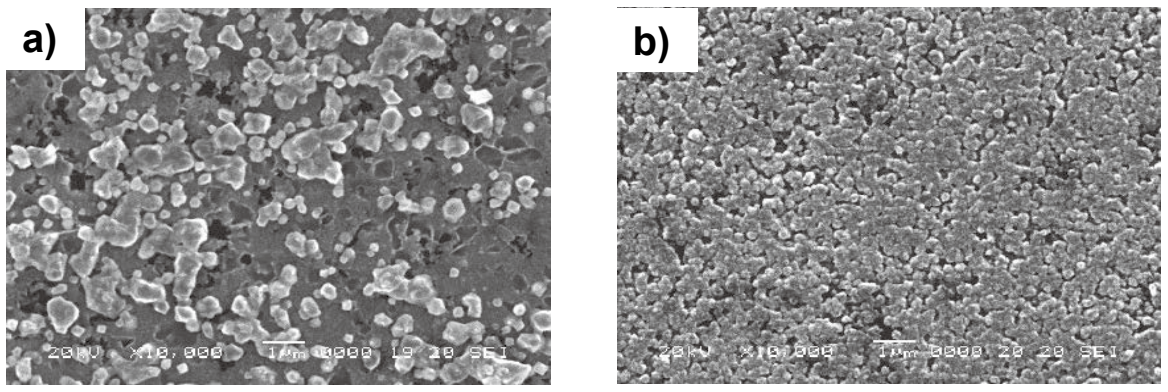

図 4 亜鉛剥離処理後の Al-Si 電極表面 a)一般用ジンケート処理，b) 薄膜用ジンケート処理
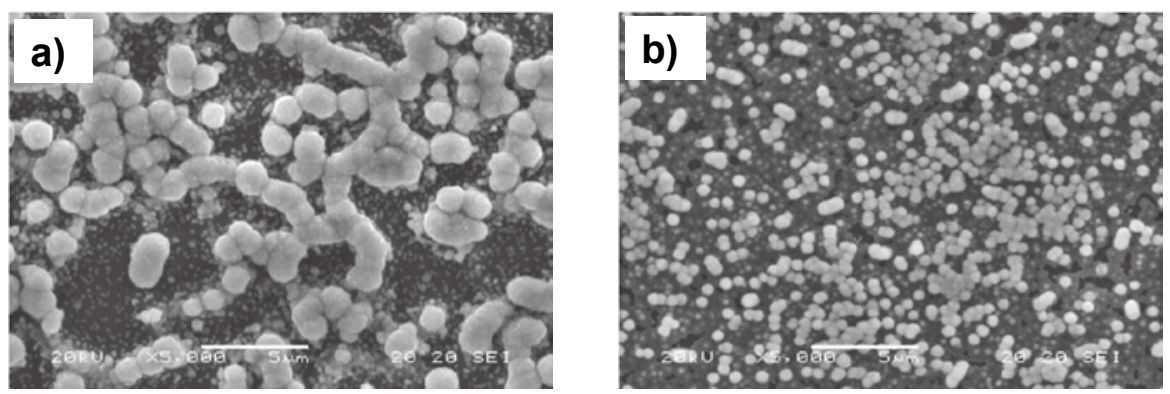

図 5 第一ジンケート処理後の Al-Si 電極表面ａ）標準工程, b) 核生成促進工程
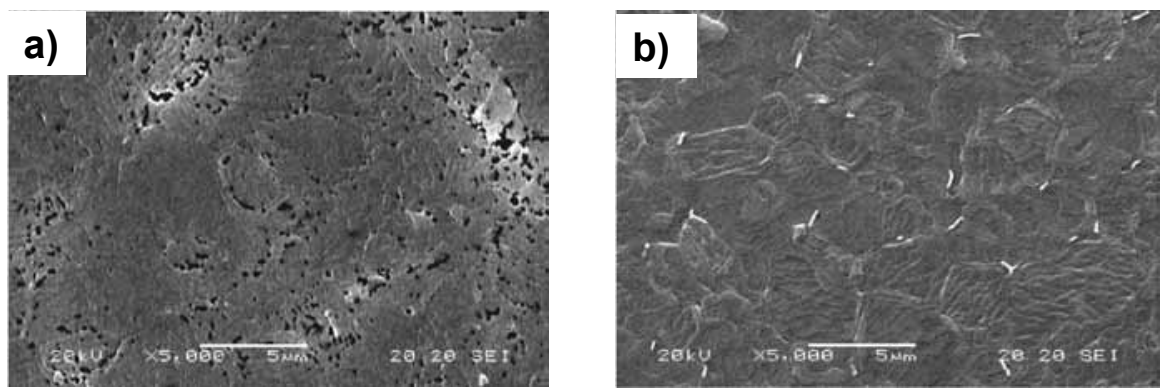

図 6 第一亜鉛置換皮膜剥離後の $\mathrm{Al}-\mathrm{Si}$ 電極表面 第一ジンケート処理；a)密着増強型ジンケート液，b) 孔食抑制型ジンケート液 


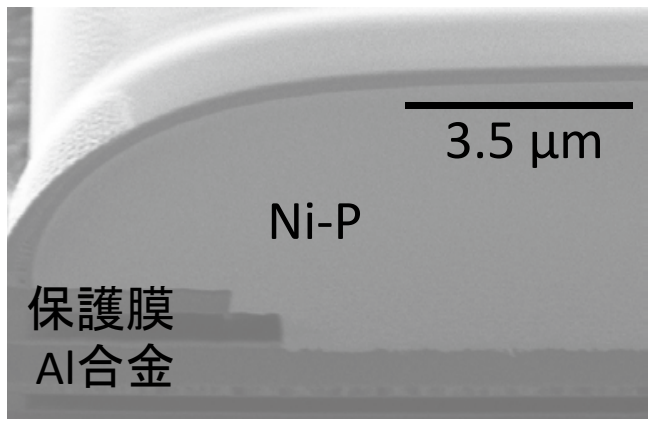

図 7 最適化したプロセスでめっきした半導体電極

無電解ニッケルめっき皮膜間の密着性の関係を評価した ${ }^{30)}$ 。 ジンケート液を第一ジンケート処理における孔食抑制重視の 組成とし, ダブルジンケート処理を行ったところ, 無電解ニッ ケルめっきの充分な密着が得られなかった。しかしながら, 第一ジンケート処理に孔食抑制重視型, 第二ジンケート処理 に密着重視型の組成を組み合わせることで，孔食が少なくか つ良好な密着の無電解ニッケルめっきを施すことが可能と なった。この概念を薄膜電極のプロセスに導入したところ, 図 $6 \mathrm{~b}$ )に示すように孔食をほぼ完全に抑制することが可能と なった。この最適化したプロセスで $\mathrm{Al}-\mathrm{Si}$ 電極をめっきする と，アルミニウム合金のエッチング，孔食がほとんどなく， スパイクの発生がない, 平滑な無電解ニッケルめっき皮膜が 得られた。過去の事例では, $200 \mathrm{~nm}$ のアルミニウム合金薄 膜へも充分な信頼性が得られる無電解ニッケルめっき電極を 形成することが可能となっている ${ }^{31)}$ 。

このように，素材に合わせてジンケートプロセスを最適化 することで，従来では困難であったアルミニウム合金薄膜へ 良好なめっきを行うことが可能となった(図 7)。

\section{5.おわりに}

ジンケート処理は 1920 年代からめっき前処理として用い られている古典的な手法であり, 先人たちの多くの研究成果 が我々の礎となっている。しかしながら，永く使われている ことはプロセスが成熟していることを必ずしも意味しない。 筆者らは, アルミニウム合金薄膜において古典的なジンケー 卜処理を再検討することで，ジンケート処理の欠点が大幅に 改善できることを見出した。現在用いられている多様な素材， あるいは今後開発される素材に対して，ジンケート処理を始 めとして, 現在使われている表面処理プロセスを最適化する ことで，より高い性能が得られる可能性があり，今後の開発 と発展を期待したい。

(Received September 30, 2013)

\section{文献}

1 ) J. O. Mallory, J. Hajdu ; Electroless plating (American Electroplaters and Surface Finishers Society, 1990).

2 ) D. S. Lashmore ; Plating \& Surface Finishing, 65, (4), 44 (1978).

3 ) E. H. Hewitson ; U. S. Patent 1,627,900 (1927).

4 ) J. Korpium ; U. S. Patent 2,142,564 (1939).

5 ) W. G. ZELLEY ; J. Electrochem. Soc., 100, (7), 328 (1953)., U. S. Patent 2,650,866 (1953)., U. S. Patent 2,676,916 (1954).

6 ) F. Keller, W. G. ZELLEY ; J. Electrochem. Soc., 97, (4), 143 (1950).

7 ) D. W. Baudrand ; Plating \& Surface Finishing, 66, (12), 14 (1979).

8 ) Y. Hirayama ; Kinzoku Hyoumen Gijyutsu, 38, (9), 378 (1987).

9 ) M. Yonemitsu, H. Ikeda ; J. Surf. Finish. Soc. Jpn., 42, (3), 323 (1991).

10) G. Moutulla, P. Kasulke, K. Heinricht, A. Ostmann, E. Zakel, H. Reichl, G. Aszdasht, J. Klöser ; Proc. IEEE/CMPT International Electronics Manufacturing Technology Symposium, p. 174 (1997).

11) S. Kawashima ; J. Surf. Finish. Soc. Jpn., 54, (2), 103 (1991).

12) D. S. Lashmore ; Plating \& Surface Finishing, 67, (1), 37 (1980).

13) D. S. Lashmore ; J. Electrochem. Soc., 127, (3), 573 (1980).

14) G. O. Mallory; Plating \& Surface Finishing, 72, (6), 86 (1985).

15) S. G. Robertson, I. M. Ritchie, D. M. Druskovich ; J. Appl. Electrochem., 25, 659 (1995).

16) S. G. Robertson, I. M. Ritchie ; J. Appl. Electrochem., 27, 799 (1997).

17) K. Azumi, M. Seo, L. Nanis ; J. Surf. Finish. Soc. Jpn., 47, (6), 529 (1996)

18) K. Azumi, Y. Fujishige, M. Seo, L. Nanis, H. Nakao, K. Tashiro ; $J$. Surf. Finish. Soc. Jpn., 47, (9), 802 (1996).

19) K. Azumi, Y. Fujishige, M. Seo, I. Saeki, L. Nanis, H. Nakao, K. Tashiro ; J. Surf. Finish. Soc. Jpn., 48, (10), 1019 (1997).

20) T. Morikawa, T. Nakade, M Yokoi ; J. Surf. Finish. Soc. Jpn., 59, (4), 257 (2008)

21) T. Nakata, I. Wada, H. Imai, K. Ikeshima, K. Inoue, T. Watanabe ; $J$. Surf. Finish. Soc. Jpn., 48, (8), 820 (1994).

22) M. Hino, K. Murakami, Y. Mitooka, M. Hiramatsu, S. Nishiyama, K. Hosokawa, T. Kanadani ; J. Surf. Finish. Soc. Jpn., 58, (8), 476 (2007)

23) K. Tashiro, K. Chiba, Y. Fukuda, H. Nakao, H. Honma ; J. Surf. Finish. Soc. Jpn., 45, (7), 720 (1994).

24) S. W. Court, B. D. Baker, F. C. Walsh ; Trans. IMF, 78, (4) 157 (2000).

25) L. Jones ; U. S. Patent 4, 205, 099 (1980).

26) K. Wong, K. Chi, A. Rangappan ; Plating \& Surface Finishing, 75, (7), 70 (1988).

27) G. Qi, X. Chen, Z. Shao ; Thin solid films, 406, 204 (2002).

28) G. Qi, L. G. J. Fokkink, K. H. Chew ; Thin solid films, 406, 219 (2002)

29) D. A. Hutt, C. Liu, P. P. Conway, D. C. Whalley, S. H. Mannan ; IEEE Trans. Comp. Packag. Technol., 25, 87 (2002).

30) Y. Koyama, K. Tashiro, K. Sekiyama, S. Kawashima ; Abst. 101th Meet., p. 262 (Surf. Finish. Soc, Jpn., 2000)

31) Private Communication 